\title{
Dependence of productive tillering of solid spring wheat on seeding rates of and importation of fertilizers
}

O. Horash, doctor of agricultural sciences

A. Kucher

Podilsky State Agrarian University of Technology

The purpose. To study of influence of seeding rates and application of fertilizers upon productive tillering of plants of wheat. Methods. Calculation, weighting and statistical. Results. Dependence of productive tillering of wheat on seeding rates and importation of fertilizers is determined. With each increase of seeding rates the productive tillering diminished. Conclusions. Application of fertilizers N30P30K30, N60P60K60 and N90P90K90 promoted gradual improvement of productive tillering in comparison with the control (NOPOKO.)

Key words: solid spring wheat, tillering, seeding rates, norms of fertilizers.

Introduction. In the technological requirements of growing crops properly installed seeding rate helps to create favorable cenotic conditions, that have significantly affect on the level of culture productivity in general. Hence, whenever there is a need to constant check of the biological objects reaction on seeding rate. Fertilizing technology is another important requirement. It is not enough of mineral nutrients in an easily accessible form in the soil to produce a high yield of wheat. So it is necessary to apply fertilizers [13].

Analysis of recent research. Wheat tillering is the biological process of forming numerous stem plants. Its implementing largely depends on agricultural background. From a biological point of view, the ability to form side shoots of the plants allows better using of growth factors to create maximum yield [46]. It should be emphasized, according to the conducted literature analysis, applied fertilizers are causing the significant impact on cereal crops tillering, nitrogen availability is especially important $[7,8]$. Intense varieties are characterized by high requirements for the nutrition conditions. Intense varieties can be generated high yields only in providing complete and balanced nutrients [9].

Materials and methods. Research was made at the training and production center's conditions "Podilya" of State Agrarian and Engineering University of Podilya. Scheme of the experiment: seeding norms - factor $A$ - 300, 350, 400 and 450 seeds $/ \mathrm{m}^{2}$; fertilizer application rate - factor $B-\mathrm{N}_{0} \mathrm{P}_{0} \mathrm{~K}_{0}$ (control - without fertilization), $\mathrm{N}_{30} \mathrm{P}_{30} \mathrm{~K}_{30}, \mathrm{~N}_{60} \mathrm{P}_{60} \mathrm{~K}_{60}$ and $\mathrm{N}_{90} \mathrm{P}_{90} \mathrm{~K}_{90}$. The object of research - durum wheat plants Isolde and Giselle varieties. . Productive tillering and yield records were set by conventional techniques highlighted by V.F.Moyseycheno., V.O.Yeschenko. The results of the experimental data were calculated using Duncan test [10].

The results of research. One of the results of the study was found the coefficient of productive tillering dependence on the norms of seeding and fertilizer application rate (Table 1). 
Table 1. Productive tillering wheat plants dependence on the effects of the seeding norms and applied fertilizer (average during 2015-2016 years)

\begin{tabular}{|c|c|c|c|c|c|c|c|c|}
\hline \multirow{2}{*}{$\begin{array}{c}\text { Norm } \\
\text { fertilizers }\end{array}$} & \multicolumn{7}{|c|}{ Varieties } \\
\cline { 2 - 9 } & \multicolumn{7}{|c|}{ Isolde } & \multicolumn{5}{c|}{ Giselle } \\
\cline { 2 - 9 } & 300 & 350 & 400 & 450 & 300 & 350 & 400 & 450 \\
\hline $\mathrm{N}_{0} \mathrm{P}_{0} \mathrm{~K}_{0}$ & 1,11 & 1,08 & 1,06 & 1,05 & 1,07 & 1,04 & 1,02 & 1,01 \\
\hline $\mathrm{N}_{30} \mathrm{P}_{30} \mathrm{~K}_{30}$ & 1,28 & 1,20 & 1,12 & 1,10 & 1,22 & 1,13 & 1,08 & 1,05 \\
\hline $\mathrm{N}_{60} \mathrm{P}_{60} \mathrm{~K}_{60}$ & 1,44 & 1,32 & 1,21 & 1,19 & 1,36 & 1,26 & 1,16 & 1,13 \\
\hline $\mathrm{N}_{90} \mathrm{P}_{90} \mathrm{~K}_{90}$ & 1,46 & 1,36 & 1,24 & 1,22 & 1,40 & 1,28 & 1,18 & 1,16 \\
\hline
\end{tabular}

According to the analysis of the factors, the standards' seed sowing increasing, leading to a significant reduction in productive tillering, which is typical for the Isolde and Giselle varieties was found (Table 2). The average rate was 1.32; it was 1.26 at a rate of 300 seeds $/ \mathrm{m}^{2}$, it was $1.24,1.18$ at a rate 350 seeds / $\mathrm{m}^{2}$, it was $1.16,1.11$ at a rate 400 seeds $/ \mathrm{m}^{2}$ and it was $1.14,1.09$ at a rate 450 seeds $/ \mathrm{m}^{2}$ according to the Isolde and Giselle varieties respectively. Seeding rates of 300 and 350 seeds $/ \mathrm{m}^{2}$ are in separate homogenous groups, significantly different from one another. Seeding rates 400 and 450 seeds $/ \mathrm{m}^{2}$ form one group and they are statistically equal. But there is a significant difference between the data rate seeding 400 and 450 seeds $/ \mathrm{m}^{2}$ and 300350 seeds $/ \mathrm{m}^{2}$. Rules regularities of seeding and fertilizer application, presented in Table 2 are similar data according to the distribution of productive tillering for homogeneous groups.

Table 2. Seeding seed norms' and fertilizer rate application's effect on wheat's productive tillering coefficient, Duncan test (average during 2015-2016 years)

\begin{tabular}{|c|c|c|c|c|c|c|}
\hline \multirow{2}{*}{$\begin{array}{c}\text { Seedin } \\
\text { g norms, } \\
\text { seeds } / \mathrm{m}^{2}\end{array}$} & \multirow{2}{*}{$\begin{array}{r}\text { Tillering } \\
\text { coefficient }\end{array}$} & \multirow{2}{*}{$\begin{array}{l}\text { Fertilizers' } \\
\text { norm }\end{array}$} & \multirow{2}{*}{$\begin{array}{r}\text { Tillering } \\
\text { coefficient }\end{array}$} & \multicolumn{3}{|c|}{ Homogenous groups } \\
\hline & & & & 1 & 2 & 3 \\
\hline \multicolumn{7}{|c|}{ Isolde variety } \\
\hline 300 & 1,32 & $\mathrm{~N}_{0} \mathrm{P}_{0} \mathrm{~K}_{0}$ & 1,08 & & & $* * * *$ \\
\hline 350 & 1,24 & $\mathrm{~N}_{30} \mathrm{P}_{30} \mathrm{~K}_{30}$ & 1,18 & & $* * * *$ & \\
\hline 400 & 1,16 & $\mathrm{~N}_{60} \mathrm{P}_{60} \mathrm{~K}_{60}$ & 1,29 & $* * * *$ & & \\
\hline 450 & 1,14 & $\mathrm{~N}_{90} \mathrm{P}_{90} \mathrm{~K}_{90}$ & 1,32 & $* * * *$ & & \\
\hline \multicolumn{7}{|c|}{ Giselle variety } \\
\hline 300 & 1,26 & $\mathrm{~N}_{0} \mathrm{P}_{0} \mathrm{~K}_{0}$ & 1,04 & & & $* * * *$ \\
\hline 350 & 1,18 & $\mathrm{~N}_{30} \mathrm{P}_{30} \mathrm{~K}_{30}$ & 1,12 & & $* * * *$ & \\
\hline 400 & 1,11 & $\mathrm{~N}_{60} \mathrm{P}_{60} \mathrm{~K}_{60}$ & 1,23 & $* * * *$ & & \\
\hline 450 & 1,09 & $\mathrm{~N}_{90} \mathrm{P}_{90} \mathrm{~K}_{90}$ & 1,26 & $* * * *$ & & \\
\hline
\end{tabular}

Regarding the influence of the applied fertilizers, it was established: productive tillering plants has upgraded by increasing of the application rate. Option without fertilizer (control) and $\mathrm{N}_{30} \mathrm{P}_{30} \mathrm{~K}_{30}$ have formed a single homogeneous group. The data rate's were in one homogeneous group in conditions of 
options for using $\mathrm{N}_{60} \mathrm{P}_{60} \mathrm{~K}_{60}$ and $\mathrm{N}_{90} \mathrm{P}_{90} \mathrm{~K}_{90}$. This indicates that the productive tillering coefficient's was statistical similarity at these mineral fertilizers application's rates. It has been always the smallest in a variant without fertilization (control) - 1.08; 1.04, Isolde and Giselle varieties. Productive tillering coefficient was slightly but more significantly in applying fertilizers $\mathrm{N}_{30} \mathrm{P}_{30} \mathrm{~K}_{30}$ variant. It was found both on Isolde and Giselle varieties, where indices were 1.18; 1.12 appropriately. Productive tillering coefficient was 1.30; 1.23 using $\mathrm{N}_{60} \mathrm{P}_{60} \mathrm{~K}_{60}$; productive tillering coefficient was 1.32; 1.26 using $\mathrm{N}_{90} \mathrm{P}_{90} \mathrm{~K}_{90}$, Isolde and Giselle varieties appropriately.

In the conducted studies the average yield of wheat grains was $4.42 \mathrm{t} /$ ha for Isolde and $4.31 \mathrm{t} /$ ha for Gisselle.The highest yield was obtained on a variant with a seed rate of 400 seeds $/ \mathrm{m}^{2}$ and $\mathrm{N}_{90} \mathrm{P}_{90} \mathrm{~K}_{90}$ application: $5.44 \mathrm{t} /$ ha - Isolde variety, $5.30 \mathrm{t} /$ ha - Giselle variety.

\section{Conclusions:}

1. Effect of seeding rules on productive tillering wheat plants firmly was established. According to the rules of the experiment seeding 300 seeds $/ \mathrm{m}^{2}$ the index was $1.33,1.26$ - average rate. According to the increasing seeding rate has reduced: according to the seeding rate of 350 seeds $/ \mathrm{m}^{2}$ it amounted to $1.24,1.18$; according to the seeding rate of 400 seeds $/ \mathrm{m}^{2}$ index was $1.16 ; 1.11$; and according to the seeding rate of 450 seeds $/ \mathrm{m}^{2}$ index was $1.14,1.09$, Isolde and Giselle varieties appropriately.

2. With fertilizers using the lowest tillering rate was under control and had averaged rate 1.08 and 1.04 during experiment. With the $\mathrm{N}_{30} \mathrm{P}_{30} \mathrm{~K}_{30}$ fertilization it was $1,18,1.12$; with the $\mathrm{N}_{60} \mathrm{P}_{60} \mathrm{~K}_{60}$ fertilization it was $1,30,1.23$; and with the $\mathrm{N}_{90} \mathrm{P}_{90} \mathrm{~K}_{90}$ fertilization it was $1,32,1.26$, Isolde and Giselle varieties appropriately.

\section{References}

1. Directory for growing winter wheat / [Vlokh V.G., Bomba M.Y., Likhochvor V.V. and other]. - Lviv: Ukrainian technology, 1998. - $149 \mathrm{p}$.

2. Likhochvor V.V. Winter wheat / V.V. Likhochvor, R.R. Protz. - Lviv: Ukrainian technology, 2002. - 88 p.

3. Horash O.S. Winter barley malting. Monograph / O.S. Horash, R.I. Klymyshena. - Kamenets: "Medobory 2006", 2014. - 216 p.

4. Savitsky M.S. Biological and agrotechnical factors of high yields of grain crops / M.S. Savitsky.Moscow, 1948.-172 p.

5. Petr J. Některé možnosti regulace výnosových prvků u obilnin / J. Petr // Sbornik referátů konf. «Agroekologické základy řešeni obilnic programů v socialistických zemich». - VŠP Nitra, 1977. (Informácie MPVž SSR, 1977, 22-23,66-69).

6. Likhochvor V.V. Optimum parameters of the winter wheat's structure / V.V. Likhochvor // Agribusiness today. - 2012. - №23 (246).

7. Kennedy S. P., Spink J. H., Binghaml. J., Identifying constraints to increasing yield potential in barley / S. P.Kennedy, J. H.Spink, I. J.Bingham // SAC Postgraduate Research Conference, 6th April 2011 Edinburgh, UK.

8. Noworolnik K. Morphological characters, plant phenology and yield of spring barley (Hordeumsativum L.) Depending on cultivar properties and sowing date / K. Noworolnik // Actaagrobotanica Vol. 65 (2). - 2012. - C. 171-176.

9. Noworolnik K. Yielding and protein content in grain of brewery cultivars of barley depending on sowing rate / K. Noworolnik // Fragm. Agron.,2008. - 1(97): C - 278-287. (in Polish).

10. Clark A. Managing cover crops profitably / A.Clark. - Beltsville: Sustainable Agriculture Network, 2007. -246 p. 